\title{
64. Evaluation of Molluscan Fossils from the Mesozoic of the Shimanto Belt
}

\author{
By Tatsuro Matsumoto and Hakuyu OKadA \\ (Communicated by Teiichi Kobayashi, M. J. A., Sept. 12, 1978)
}

To know the implications of the newly found ammonite reported in the preceding article, we compile in this paper the hitherto known records of ammonites and other molluscan fossils from the Mesozoic part of the Shimanto Group of Southwest Japan and give general remarks how to evaluate them.

The following are the hitherto known records, showing specific names, formation, locality or area, geological age, and reference. They are arranged geographically from SW to NE (Fig. 1). Some poorly studied material may be omitted, if other better studied information is available in the same formation or area.

(1) Collignoniceras (Selwynoceras) sp. nov.(?), Ohgachi Formation (shale and sandstone), Amami-Oshima, Turonian (Matsumoto et al., 1966).

(2) Scalarites spp., Polyptychoceras cf. obstrictum (Jimbo), P. (Subptychoceras) cf. yubarense (Yabe), Muniericeras(?) sp., Inoceramus cf. mihoensis Matsumoto, I. (Platyceramus) cf. yubarensis Nagao and Matsumoto and Acila sp., unnamed formation (massive shale and thick-bedded sandstone), $1 \mathrm{~km}$ north of Kawanabe, Kagoshima Prefecture, Upper Coniacian (Matsumoto et al., 1973).

(3) Neophylloceras subramosum Spath, Tetragonites sp., Anagaudryceras limatum (Yabe), Gaudryceras denseplicatum (Jimbo), G. tenuiliratum Yabe, Eubostrychoceras sp., Polyptychoceras cf. pseudogaultinum (Yokoyama), Baculites yokoyamai Tokunaga and Shimizu, B. schencki Matsumoto, Scaphites pseudoequalis Yabe, Otoscaphites (Hyposcaphites) matsumotoi Tanabe, Damesites damesi (Jimbo), Kossmaticeras sp., Forresteria (Muramotoa) aff. muramotoi Matsumoto, Subprionotropis aff. columbianus Basse, Protexanites cf. bontanti (Grossouvre), P. (Anatexanites) fukazawai (Yabe and Shimizu), Inoceramus (Inoceramus) cf. hobetsensis Nagao and Matsumoto, I.(I.) cf. teshioensis N. and M., $I .(I$.$) tenuistriatus N. and M., I .(I$. uwajimensis Yehara, I. mihoensis Matsumoto, I. (Cordiceramus) cordiformis Sowerby, I. (Mytiloides) cf. incertus Jimbo, I. (Platyceramus) amakusensis N. and M., I. (Sphenoceramus) cf. cardissoides Goldfuss, I. (S.) naumanni Yokoyama, I. (S.) nagaoi Matsumoto and Ueda, I. (Endocostea) balticus Böhm, Didymotis akamatsui (Yehara) and many other mollusca including Amphidonta sp. and Caprina uwajimensis Shikama and Tanabe (top member), various levels of the Uwajima Group, many localities in Uwajima area, Ehime Prefecture, Turonian-Coniacian-Santonian (Yehara, 1924; Shikama and Tanabe, 1970; Tanabe, 1972; Teraoka and Obata, 1975; Matsumoto, 1978).

Also Inoceramus aff. crippsii Mantell from the Shitaba Formation, which may be included in the Uwajima Group, Cenomanian (Matsumoto, ed., 1954).

(4) Cheloniceras shimizui Nakai and Hada and Ch. aff. minimum Casey 


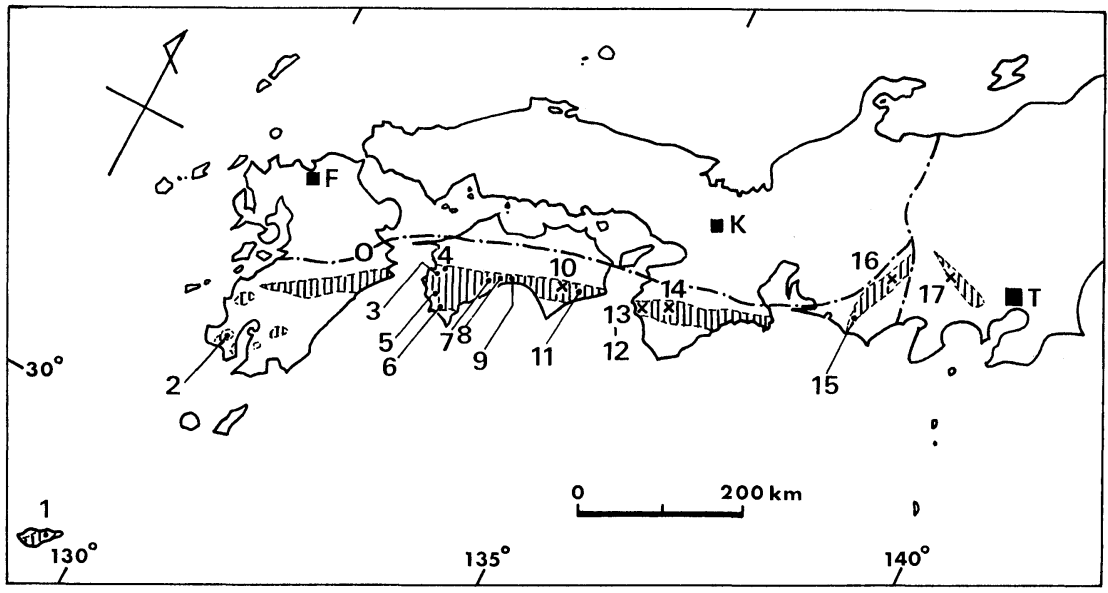

Fig. 1. Map of Southwest Japan, showing the outcropping Mesozoic part of the Shimanto Group (hatched) and locations of ammonites (solid circle) and other molluscan fossils ( $X$ without ammonite). 1-17 correspond to the numbers annotated in the text. O, Onogawa basin; F, Fukuoka; $\mathrm{K}$, Kyoto and $\mathrm{T}$ : Tokyo.

from an unnamed formation (sandy siltstone and sandstone, with lenticular limestone containing calcareous algae) near Chikanaga, adjacent to the northeast of Uwajima, Ehime Prefecture, Aptian (Nakai and Hada, 1966).

(5) Maorites sp., Polyptychoceras sp., Diplomoceras (?) sp., Inoceramus (Endocostea) balticus Böhm, I. (Spheoceramus) schmidti Michael, I. (Cordiceramus) yuasai Noda and some other mollusca from the second member (mudstone with sandy laminae or thin layers) of the Johen Formation, near Johen, Ehime Prefecture, Campanian (Katto, 1961; Noda, 1974; Tanaka, 1977).

(6) (a) Gaudryceras aff. denmanense (Whiteaves), Baculites sp., Solenoceras sp., Glyptoxoceras cf. indicum (Forbes), and Natalites (?) sp., lowest member " $\mathrm{Nk}_{1}$ " (thick bedded mudstone and sandstone) of the Nakamura Formation, several localities between Sukumo and Nakamura, Kochi Prefecture, Campanian; (b) Inoceramus (Platyceramus) aff. vanuxemiformis Nagao and Matsumoto, I. (Endocostea) balticus kunimiensis N. and M., I. (Sphenoceramus) orientalis Sokolow and other mollusca, the second member " $\mathrm{Nk}_{2}$ " (mudstone), Nakamura Formation, Sukumo-Nakamura area (Tanaka, 1977) ; (c) "Vertebrites kayei (Forbes)", boulder from the Nakamura Formation, Maastrichtian (?) unless misidentified (Katto, 1961); (d) Aphrodina hataii Katto and Hattori and $A$. cf. pseudoplana (Yabe and Nagao), Nakamura Formation (Katto and Hattori, 1964).

(7) Stoliczkaia japonica (Matsumoto) (at Taru), Neophlycticeras (?) sp. (at Nii), Inoceramus cf. anglicus Woods and Solemya sp., Susaki Formation (shale with chert and basaltic green rock) several localities to the southwest and south of Kochi, Upper Albian and thereabout (Matsumoto et al., 1952; Katto and Ozaki, 1956; Matsumoto and Hirata, 1969).

(8) Diplasioceras tosaense (Matsumoto and Hirata) (at Azai), Diploceras aff. fredericksburgense Scott (at Kitayama) and an indeterminable heteromorph ammonite, Hayama Formation (dark green-grey shale and sandstone), distributed to the north of Susaki Formation in fault contact, 
Kochi Prefecture, Albian (lower Upper Albian) (Matsumoto et al., 1952; Matsumoto and Hirata, 1969; Katto and Obata, 1975).

(9) Neithea (Neithea) matsumotoi Hayami, N. (N.) kochiensis Hayami, Plicatula sp., Amphidonte (Amphidonte) subhaliotoidea (Nagao) and Pterotrigonia hokkaidoana (Yehara), Doganaro Formation (sandy siltstone, mudstone, and sandstone with lenticular limestone containing hexacorals, hydrozoa and stromatopora adjacent to the north of Hayama Formation and immediate to the south of the Butsuzo Tectonic Line, Kochi Prefecture, Lower Cretaceous (Hayami and Kawasawa, 1967).

(10) Tylostoma (?) sanchuense (Yabe and Hanzawa), Cassiope neumayri (Nagao), Astarte (Nicaniella) semicostata Nagao etc., Nakagawa Formation (clayslate with lenticular sandstone, immediately to the south of the Butsuzo Line), Nonoshiri (Furuya), Kaminaka, Tokushima Prefecture, Lower Cretaceous (Shinoaki, 1958; Nakagawa et al., 1977a).

(11) Vertebrites cf. kayei (Forbes), Furumugi Formation (mudstone containing calcareous nodules, with thin layers of sandstone), near Mugi, Tokushima Prefecture, Maastrichtian (Suyari et al., 1967; Nakagawa et al., 1977b).

(12) Inoceramus (Platyceramus) cf. amakusensis N. and M., $I .(P$.$) cf.$ ezoensis Yokoyama and $I$. $(P$.$) cf. cyeloides Wegner, middle part (shale$ with sandstone) of Terasoma Formation, Terasoma, Wakayama Prefecture, Santonian (Morozumi, 1970).

(13) Acila (Truncacila) n. sp., Mesosaccella sp., Nanonavis (N.) cf. sachalinensis (Schmidt), Inoceramus (Mytiloides) aff. labiatus (Schlotheim) and Periploma sp., upper part of Shirama Formation (?), Kawase (about $3 \mathrm{~km}$ to the northwest of Terasoma), Wakayama Prefecture, Upper Cretaceous (Hashimoto, 1968).

(14) (a) Spondylus sp., Plicatula sp., Amphidonta sp., Lopha (?) sp. etc., Yukawa Formation (sandstone and shale), Lower Cretaceous (?) ; (b) Inoceramus (Birostrina) concentricus nipponicus N. and M., shale higher than (a), Yukawa, Wakayama Prefecture, Cenomanian (?), (Nakazawa, 1973).

(15) Hauericeras (Gardeniceras) cf. rembda (Forbes), contorted mudstone containing concretion, with some chert and green basaltic rock, Tadaki (Tenryu), Shizuoka Prefecture, Upper Cretaceous (probably Maastrichtian) (Matsumoto et al., preceding article).

(16) Pachytraga japonica Okubo and Matsushima, boulder from the Shimanto Group of Akaishi Mountains, Shirane area, Nagano Prefecture, Cretaceous (Okubo and Matsushima, 1959).

(17) Inoceramus sp., Kobotoke Formation (alternating sandstone and shale), Yozawa (Kosuge), Yamanashi Prefecture, Upper Cretaceous (Nishimiya, 1976).

Attempts to subdivide the Shimanto Group have recently been made to a considerable extent by a number of field geologists in various areas. As a result numerous formations have been proposed with local names (e.g., see Nakazawa, 1973, table 1), but correlation of them between separated areas is very difficult because of the scarcity of available fossils and the abundance of thrusts and other faults.

Some authors have looked for general rules which may have controlled the stratigraphic sequences of the Shimanto Group. Okada 
(1971) suggested a coarsening-upwards cycle in a part of the Shimanto Group on the evidence of the sequence in area (5). Tanaka (1977) has ascertained the same rule more comprehensively and recognized at least three major cycles within the Cretaceous. In each cyclic sequence claystone is more predominant in the lower part and sandstone is so in the upper part, although there may be lateral changes of facies, as Tanaka himself has shown examples.

Another important idea about the sedimentary and tectonic framework of the Shimanto Group is that which attempts to compare it actualistically with the arc-trench framework around the Pacific ocean, as represented schematically by Kanmera (1976, fig. 9) and Dickinson (1977, fig. 2). In the model of that idea the deposits of the basin urider the "terrace" of the arc-trench gap and those of the lower slope or trench slope, with some smaller benches, should be distinguished. A shallowing-upwards sequence may be commonly developed in the terrace or bench deposits. The deposits under the lower slope may be generally finer, much deformed and may contain basaltic green rock and chert. The arc-trench gap framework seems to have migrated outward, forming accretionary wedges, from period to period.

If the above generalized model is applicable to the Shimanto Group, as it is likely so, macro-fossils should be allocated properly to a particular position of the framework to tell the geological age and the environments of a concerned formation. To exemplify this we give tentatively the following remarks $(\mathrm{A}-\mathrm{H})$ :

(A) Many of the molluscan fossils, especially those showing less isolated occurrence, may have been embedded in the terrace deposits and only a few may be concerned with the lower slope deposits, either in situ or intermingled by slumping.

(B) The cases of Tadaki (15), Furumugi (11) and probably also Susaki (7) can be interpreted as examples which may have constituted the lower slope, because the clayey rock of the host formation is highly contorted and because similar nodule-bearing claystone is actually detected under the modern trench slope (Site 434, IPOD/ DSDP Leg 56 ; Langseth, Okada et al., 1978).

(C) It is interesting to see that (7) is Upper Albian or thereabout, whereas (11) and (15) is Maastrichtian. Trench-slope deposits could be of any age, in accordance with the phase of an accretionary process.

(D) Certain groups of ammonites and certain kinds of inocerami of pelagic nature can occur in any part of marine sediments, but the marine facies of shallower depths may be more favourable for the occurrence of ornate ammonites. As has already been pointed for 
(Matsumoto and Hirata, 1967), some of these ammonites are adult, with a well preserved living chamber, as seen in the case of the Hayama Formation (8). This suggests that they were embedded under a calm condition on the sea bottom in generally the same place or not far from their original habitat of shallow to moderate depths.

(E) Many of other bivalvian and gastropod faunas suggest sediments of shallower seas, but they could be intermingled with the sediments of deeper part as olistoliths or reworked fossils. The latter case could possibly be considered for (9) and (10) as suggested by Kanmera (personal communication), although more careful investigation is needed.

(F) We would generally agree with Tanaka (1977) in considering that the later phases of major cycles may be indicated by fossil records of (4), (8) and probably (9) (Aptian-Albian) for the first cycle, those of (3) (Upper Turonian-Santonian) for the second cycle and those of (5) and (6) (Campanian and also ?Maastrichtian) for the third cycle.

(G) The terrace deposits could be of dissimilar depths, as seen in modern examples. The Uwajima Group (3), which contains exceptionally fossiliferous parts for the Shimanto belt, may represent the deposition of a basin of shallower terrace and may have had a direct connection with the Onogawa basin (indicated as $O$ in Fig. 1) of central Kyushu.

(H) Being stimulated by successful works of Passagno (1976, 1977) in the Jurassic and Cretaceous of California, radiolarian faunas of the Shimanto Group have recently begun to be studied with some promising results (Nakagawa and Nakaseko, 1977). According to them Neocomian (i.e. pre-Aptian part of Lower Cretaceous) and Tithonian faunas are found in certain parts. Radiolaria are better preserved in cherty rocks and these rocks may occur more frequently in the lower part of a major cycle. It may correspond to the underlying part in the terrace basin or constitute the thrust wedges of the trench slope which was accreted from previous trough deposits. Anyhow, speaking generally, macro and micro-fossils are complementary with each other for the biochronology of the Shimanto Group. Occasionally they may occur in the same formation, if not at the same locality.

To sum up, the above remarks are tentative suggestions which may be served for further improvements in the study of the Shimanto Group. For encouragement to complete this paper, our sincere gratitude is due to Professor Emeritus Teiichi Kobayashi, M. J. A., to whom this paper is dedicated on the occasion of his 77th birthday. 


\section{References}

Dickinson, W. R. (1977) : $\mathrm{E} \oplus \mathrm{S}$, Amer. Geoph. Union, 58(10), 948-952.

Hashimoto, I. (1968) : Geol. Rep., Gen. Educ. Kyushu Univ., 15, 57-66.

Hayami, I., and Kawasawa, K. (1967) : Trans. Proc. Palaeont. Soc. Japan (N. S.), no. $66,73-82$, pl. 9 .

Kanmera, K. (1976) : Kagaku (Iwanami), 46(5), 287-291.

Katto, J., and Hattori, M. (1964) : Res. Rept. Kochi Univ., ser. I, 13(2), 7-10, pl. 1.

Katto, J., and Obata, I. (1975) : Mem. Nat. Sci. Museum, no. 8, 27-31.

Katto, J., and Ozaki, H. (1956) : Res. Rept. Kochi Univ., 5 (10), 1-3, pl. 1.

Langseth, M., Okada, H., et al. (1978) : Geotimes, 25, 22-26.

Matsumoto, T. (ed.) (1954): The Cretaceous System in the Japanese Islands, Japan Soc. Prom. Sci., Tokyo (for 1953), xiv+324 pp.

Matsumoto, T. (1978) : J. Geogr. (Tokyo), 87 (2), 82-89.

Matsumoto, T., and Hirata, N. (1969) : Trans. Proc. Palaeont. Soc. Japan (N. S.), no. 76, 177-184, pl. 20.

Matsumoto, T., Ishikawa, H., and Yamakuchi, S. (1966) : Ibid., no. 62, 234-241.

Matsumoto, T., Kimura, T, and Katto, J. (1952) : Mem. Fac. Sci., Kyushu Univ., ser. D, $3(4)$, 179-186, pl. 13.

Matsumoto, T, Otsuka, H., and Oki, K. (1973) : J. Geol. Soc. Japan, $79(10)$, 703-704.

Morozumi, Y. (1970): Bull. Osaka Museum Nat. Hist., no. 23, 19-24, pls. 2-4.

Nakai, I., and Hada, S. (1966) : Trans. Proc. Palaeont. Soc. Japan (N. S.), no. $62,242-250$, pls. $29,30$.

Nakagaŭa, Ĉ., kaj Nakaseko, K. (1977) : J. Gakugei, Tokushima Univ. (Nat. Sci. ), 28, 17-25, pls. 1-4.

Nakagaŭa, $\hat{\mathrm{C}}$. et al. (1977a) : Ibid., 28, 1-8, 2 folded maps. (1977b) : Ibid., 28, 9-15, 2 folded maps.

Nakazawa, K. (1973) : Symposium Volume "Shimanto Geosyncline" (Wakayama Univ.) (Harata, T. ed.), pp. 125-132.

Nishimiya, K. (1976) : J. Geol. Soc. Japan, 82, 795-796.

Noda, M. (1974) : Trans. Proc. Palaeont. Soc. Japan (N. S.), no. 93, 240-248, pl. 3.

Okada, H. (1977) : Sci. Rept. Dept. Geol. Kyushu Univ., 12(3), 203-214.

Okubo, M., and Matsushima, N. (1959) : Chikyu-kagaku, no. 42, 1-4.

Passagno, E. A., Jr. (1976) : Micropaleont., Spec. Publ., no. 2, 1-96, pls. 1-14. (1977) : Micropaleont., 23(1), 56-113, pls. 1-12.

Shikama, T., and Tanabe, K. (1970): Sci. Rept. Yokohama Nat. Univ., ser. 2, no. $17,49-58$, pls. 6-7.

Shinoaki, S. (1958) : J. Geol. Soc. Japan, 64, 95-96.

Suyari, K., Bando, H., and Obata, I. (1967) : Ibid., 73, 535-536.

Tanabe, K. (1972) : Ibid., 78, 177-190.

(1977) : Bull. Geol. Surv. Japan, 28(7), 461-476.

Teraoka, Y., and Obata, I. (1975): Mem. Nat. Sci. Museum, no. 8, 5-20, pls. 1-2.

Yehara, S. (1924) : Japan. J. Geol. Geogr., 3, 27-39, pls. 2-4. 